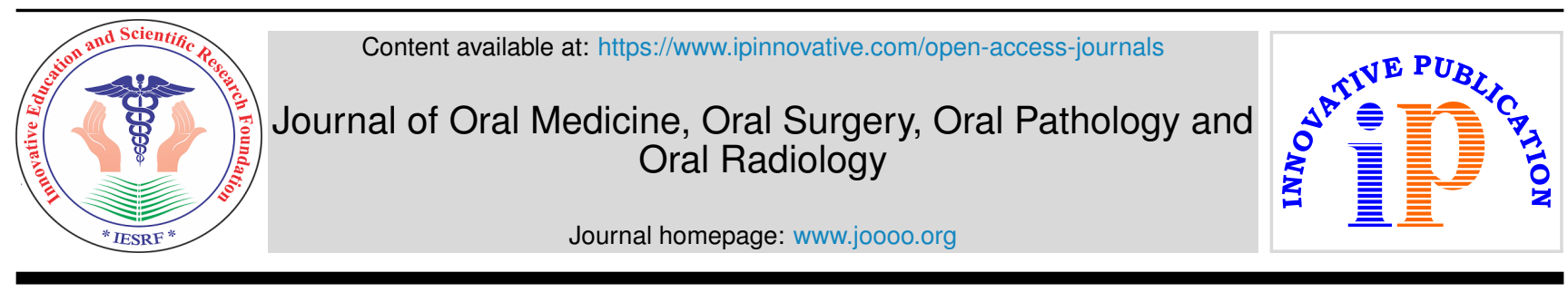

\title{
Editorial
}

\section{Tech-teach: Innovations in oral pathology teaching learning experiences}

\author{
Ketki Kalele ${ }^{\circledast 1, *}$ \\ ${ }^{1}$ Dept. of Oral Pathology and Microbiology, V.Y.W.S Dental College and Hospital, Maharashtra, India
}

\section{A R T I C L E I N F O}

Article history:

Received 20-12-2021

Accepted 25-12-2021

Available online 14-01-2022
This is an Open Access (OA) journal, and articles are distributed under the terms of the Creative Commons Attribution-NonCommercial-ShareAlike 4.0 License, which allows others to remix, tweak, and build upon the work non-commercially, as long as appropriate credit is given and the new creations are licensed under the identical terms.

For reprints contact: reprint@ipinnovative.com
Last couple of years has proved to be the table turners for the complete healthcare and educational system wherein things have gone from physical to virtual in no time. This scenario especially was put to trial for medical and dental education as pandemic related norms did not allow physical opening of the colleges and laboratories and students were deprived of the quality education and experience that is essential for budding doctors.

But as they say that "necessity is the mother of invention"; hence COVID times also witnessed many innovative techniques to foster the education standards of colleges and related healthcare courses.

Through the present editorial, my aim is to highlight the novel and the most effective techniques which have emerged with the help of technology especially in the field of pathology in general which can be applied to oral pathology teaching in specific. This can yield a great deal of improvement not only in learning of the subject but also grooming skill set that is required for building a good oral pathology practice.

\section{Innovative Teaching Technologies in Pathology}

The conventional classroom that had aggregation of students with teacher got replaced by "Google classroom" and virtual teaching with institutional email addresses of the students and teachers linked to the platform. This also facilitated

\footnotetext{
* Corresponding author.

E-mail address: drketkikalele@gmail.com (K. Kalele).
}

reminders for the classes through Google calendar to all of them and presentation of the teachers were uploaded in the Google classroom streams. ${ }^{1}$

Along with the lecture presentations of the staff huge online source was possible to utilize which included youtube videos, content from various websites, certain pathology apps which made the teaching learning experience a lot more vibrant and diverse. ${ }^{1,2}$

\section{Laboratory Teaching}

Theory classes are still better to monitor as it is mostly receptor mode, however, when it comes to practical demonstration giving the students diagnostic skills without the feel and touch of microscopes and slides was a challenge. This was to a great extent overcome with the use of webcam and microscope mounted camera which was utilised to view microscopic sections of blood smears and cystic aspirates and histopathology slides through live streaming. ${ }^{2,3}$

\section{Patient Examination and History Taking}

Any diagnosis cannot be made solely on the basis of microscopy. Examination of the pathology, history of the associated lesion, case history, getting to the differential diagnosis and then to a provisional diagnosis is far more important for accurate diagnosis work up. For this, Case based learning approach (CBL) was used with maximum efficacy which promoted in-depth knowledge of the given 
pathologies and also inculcated a sense of self-study amongst the students. ${ }^{3,4}$

CBL involved an integrated approach to the case from pathology, medicine and surgical point of view. The students divided in various batches focused on the specific problem (diagnosis of the lesion) and their advanced discussion by the guide and other subject experts about the lesion developed a more motivated and thorough learning experience to students. ${ }^{4}$

\section{Flipped Classroom Learning/Inverted Classroom}

This model was first introduced long back in the year $2000 ;^{5}$ but its application got a boom in this pandemic. Flipped classroom model promotes pre sharing of the digital study material by the mentor which the students read and prepares before the discussion. Later on, the well prepared students engage themselves in discussions and fruitful debate over the topic which fosters their engagement in the subject and freely available study material at a button click is always enjoyable. ${ }^{3,5}$

\section{Evidence Based Learning}

This involves knowledge of current researches that had taken place in the field and its application in clinical settings and decision making for pathologies. Getting virtual also gives more access to the research papers and current trends which could be read and applied by the students and teachers in their diagnostic work up. ${ }^{6}$

\section{Virtual Stimulators}

These have emerged enormously in many developed nations in this pandemic era; wherein, Virtual stimulatory technology was used to provide the tactile and motor skills for dental students in their preclinical settings. ${ }^{3}$

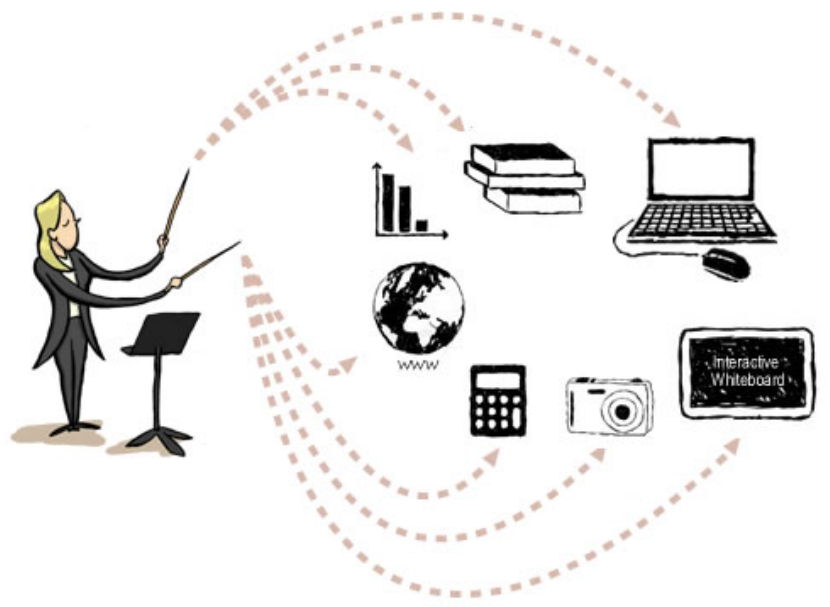

In pathology settings, virtual cases simulating real-life patient scenarios were created. These cases were those which were already covered in the theory classes. Video editing software's were used which were compatible with android phonesiphones at the same time and short videos depicting each case scenario of pathological entities were uploaded for small group of students each time. The students were then asked to discuss and put their queries on the case on Google live stream. Photomicrographs of gross specimen, clinical and histopathological images were uploaded by the staff as per the queries from the students. The students were also given some web addresses of the pathology related sites and books for self-learning. Once the students independently came to a final diagnosis, the mentors from various specialities including medicine and surgery would come to discussion of the pathology on its management part via Google meet. ${ }^{1,2,7}$

This was in a way best possible use of technology that we learnt in the lockdown period. I, through my editorial want to emphasize that although we have re started our physical classroom culture, we can still incorporate certain technological aspects to our regular teaching learning process in the best interest of our students as well as teachers. These small up gradations can transform the regular dryness of the subject into absolute delight.

\section{References}

1. Mukhopadhyay S, Joshi D, Goel G, Singhai A, Kapoor N. Evolution of pathology teaching for MBBS students during COVID-19 pandemic lockdown: Moving from a real to a virtual classroom. Indian J Pathol Microbiol. 2021;64(3):524-7.

2. Wolpaw TM, Wolpaw DR, Papp KK. SNAPPS: A learner-centered model for outpatient education. Acad Med. 2003;78(9):893-8.

3. Ramasamy S, Pavithran VK, Anjalin JR. An insight on innovative teaching strategies: A cross-sectional survey among the oral medicine and radiology faculties in Tamil Nadu and Pondicherry. India J Indian Acad Oral Med Radiol. 2020;32(3):247-52.

4. Thistlewaite JE, David D, Ekeocha S, Kidd JM, Dougall CM, Matthew P. The effectiveness of case-based learning in health professional education. A BEME systematic review: BEME Guide No. Med Teach. 2012;34(6):421-44.

5. Hu X, Zhang H, Song Y, Wu C, Yang Q, Shi Z. Implementation of flipped classroom combined with problem\&\#8209; based learning: An approach to promote learning about hyperthyroidism in the endocrinology internship. BMC Med Educ. 2019;19:290.

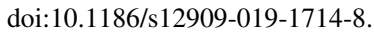

6. Larse CM, Terkelsen AS, Carlsen AF, Kristensen HK. Methods for teaching evidence-based practice: A scoping review. BMC Med Educ.

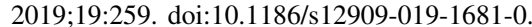

7. Black CC. Experiential teaching paradigms: Adapting the medical education literature to academic pathology practice. Acad Pathol. 2019;6. 10i:10. 17712374289519892553

\section{Author biography}

Fig. 1: 
Ketki Kalele, Assistant Professor, Editor-in-Chief (JOOO)

Dept. of Oral Pathology \& Microbiology,

V.Y.W.S Dental College and Hospital,

Maharashtra, India https://orcid.org/0000-

0003-3627-142x (D) https://orcid.org/0000-0003-

1900-0847
Cite this article: Kalele K. Tech-teach: Innovations in oral pathology teaching learning experiences. J Oral Med, Oral Surg, Oral Pathol, Oral Radiol 2021;7(4):203-205. 